\title{
3-Alkyl-5-amino-1,2,4-triazoles synthesized from the fatty acids of sunflower oil processing waste as corrosion inhibitors for copper in chloride environments
}

\section{D.S. Shevtsov, ${ }^{1}$ Kh.S. Shikhaliev, ${ }^{1 *}$ N.V. Stolpovskaya, ${ }^{1}$ A.A. Kruzhilin, ${ }^{2}$ A.Yu. Potapov, ${ }^{1}$ I.D. Zartsyn, ${ }^{1}$ O.A. Kozaderov, ${ }^{1}$ D.V. Lyapun, ${ }^{1}$ C. Prabhakar ${ }^{3}$ and A. Tripathi ${ }^{3}$}

${ }^{1}$ Voronezh State University, Universitetskaya pl. 1, Voronezh, 394018, Russian Federation

${ }^{2}$ Voronezh State Agrarian University named after Emperor Peter the Great, ul. Michurina, 1, 394087 Voronezh, Russian Federation

${ }^{3}$ National Institute of Technology Kurukshetra, Kurukshetra, 136119, India

*E-mail: shikh1961@yandex.ru

\begin{abstract}
Aminoazoles and their derivatives are widely used as corrosion inhibitors for metals. The introduction of a hydrophobic substituent into the aminoazole molecule causes a significant increase in inhibition. New promising corrosion inhibitors for copper of 3-alkyl-5-amino- $1 \mathrm{H}$ 1,2,4-triazoles were synthesized from fatty acids of sunflower oil processing waste by interaction with aminoguanidine under different conditions. New approaches to the application of renewable materials are of indisputable interest for a higher-level of chemical processing of plant oils. The protective effect of 3-alkyl-5-amino- $1 \mathrm{H}-1,2,4$-triazoles synthesized from fatty acids against the corrosion of copper in chloride media was studied using polarization curves, electrochemical impedance spectroscopy, and full-scale corrosion testing. It was determined that it is less efficient to directly add the substance to the solution. It is more beneficial to preliminary hold metal in a non-aqueous solution. The most promising application method for 3-alkyl-5-amino-1H-1,2,4-triazoles synthesized from fatty acids is inter-operational protection of copper products. SEM method determined that polarization in presence of the compounds did not cause the formation of pitting. The accelerated corrosion testing in the salt spray cabin demonstrated up to a 70-fold increase in time before corrosion damage. The protection degree in an $\mathrm{HCl}$ solution can reach $99 \%$.
\end{abstract}

Keywords: copper, corrosion inhibitor, chloride, triazole derivatives, waste of vegetable oil, fatty acid.

Received: April 8, 2020. Published: May 28, 2020

doi: $\underline{10.17675 / 2305-6894-2020-9-2-21}$

\section{Introduction}

Copper and its alloys are widely used in industry due to their high thermal conductivity, manufacturability and low cost. However, when exposed to liquid media, copper undergoes uniform or local corrosion. Uniform corrosion is most characteristic of acidic media up to 
$\mathrm{pH}=6[1]$, while in a neutral medium, corrosion can occur both uniformly and locally. The presence of activating ions, such as chlorides, stimulates local (pitting) corrosion [2-4]. Copper products can also be corroded at the storage stage after production prior to commissioning [5], therefore measures are necessary for inter-operational corrosion protection. Thus, the widespread use of copper products requires the selection of an optimal protection method.

Organic inhibitors are widely used for anti-corrosion protection of copper and copperbased alloys in water solutions [6,7]. A protective effect was found for organic compounds containing nitrogen, sulfur, phosphorus or oxygen heteroatoms, polar groups, benzene and heterocyclic rings with delocalized $\pi$-electrons [8-11].

There are quite a number of substances that produce an anti-corrosion effect on copper. Azole derivatives have proven to be the most effective inhibitors of copper corrosion [1020]. For example, the protective effect of benzotriazole (BTA), which is a fairly universal inhibitor for various environments, has been well studied [14, 17, 21]. However, BTA is toxic [22]. The availability of raw materials and the optimal cost of the final product are one of the key points in the development of corrosion inhibitors. In this regard, an active search is currently underway for more effective corrosion inhibitors based on extracts of natural compounds [23-25] or their synthetic derivatives [26, 27]. The use of industrial waste is also a promising area for these purposes [28].

Fatty acids are widely used to obtain a wide range of compounds, including corrosion inhibitors of various metals [29]. For example, it was found that fatty acid hydrazides and thiosemicarbazides [30], soybean oil derivatives containing a Schiff base [31] inhibit steel corrosion. Anticorrosive action was also noted for heterocyclic derivatives of fatty acids, such as imidazoles [32] and 3-alkyl-5-mercapto-1,2,4-triazoles [33].

Thus, the solution of the problem of introducing new inhibitors into the practice of anticorrosive protection can be divided into two successive stages:

1) reagent selection and synthesis of a new inhibitor, isolation and structure proof of the target product or group of products;

2) performing a set of corrosion tests to assess the protective properties of the substance in a particular environment, the effective concentrations and the method of processing the metal inhibitor.

The aim of this work was the synthesis of previously unknown 3-alkyl-5-amino- $1 \mathrm{H}$ 1,2,4-triazoles from sunflower oil processing waste products and the study of their protective effect on copper M1 against atmospheric corrosion and corrosion in chloride media by electrochemical methods and natural condition test. 


\section{Experimental}

\section{Materials}

The sunflower oil processing waste, a mixture of fatty acids of sunflower oil, was provided by EFKO GC (Alekseevka, Belgorod region, Russia) (acid index $193.9 \mathrm{mg} \mathrm{KOH} / \mathrm{g}$ ). The composition of the mixture according to GHMS analysis is given in Table 1. Other reagents (aminoguanidine, toluene, xylene, butanol) were purchased from commercial suppliers and used as received (Acros Organics).

All synthetic procedures were carried out in a batch reactor UNIC-150-2 (Lenz Laborglas GmbH \& Co. KG, Wertheim, Germany) with reaction vessel (volume $2 \mathrm{~L}$, with a thermostatic jacket and bottom discharge valve), which could be equipped with a reflux condenser, dropping funnel, and so on. Heating of the reaction mass was carried out with a Huber CC-202 circulation thermostat with a Pilot ONE controller providing a temperature constancy of $0.02^{\circ} \mathrm{C}$ (Peter Huber Kältemaschinenbau AG, Offenburg, Germany). The reaction mixture was stirred using an overhead stirrer IKA-Werke Eurostar 40 digital with electronic speed control (vacuuming was carried out using chemistry pumping unit PC 3004 VARIO, capable of full recovery of solvent, efficient recycling, and active environmental protection (Vacuubrandt $\mathrm{GmbH}+\mathrm{Co}$. KG, Wertheim, Germany). NMR ${ }^{1} \mathrm{H}$ spectra were registered on Bruker DRX $500(500.13 \mathrm{MHz})$ spectrometer in DMSO-d 6 , internal standard was TMS.

The acid values of products were calculated by the known techniques. Gas chromatography-mass spectrometric (GC-MS) analysis was carried out using an Agilent Technologies 7890B GC system with an Agilent Technologies mass-selective detector 5977A MSD (Agilent Technologies, Santa Clara, CA, USA). Sample inlet temperature was $280^{\circ} \mathrm{C}$, analytic interface $-150 / 230^{\circ} \mathrm{C}$. Electron impact ionization energy was $70 \mathrm{eV}$. Separation was done on a VF-23MS capillary column $(20 \mathrm{~m} \times 0.150 \mathrm{~mm} \times 0.15 \mu \mathrm{m}$, stationary phase-(90\% 3-cyanopropyl) $10 \%$ phenylmethylpolysiloxane). The gas flow rate was $1.0 \mathrm{~mL} \cdot \mathrm{min}^{-1}$, with continuous flow. The sample volume was $1 \mu \mathrm{L}$; split injection-40:1. Temperature regimes were as follows: isotherm $120^{\circ} \mathrm{C}(2 \mathrm{~min})$, heating at $10^{\circ} \mathrm{C} \cdot \mathrm{min}^{-1}$ to $180^{\circ} \mathrm{C}(1 \mathrm{~min})$, heating at $3^{\circ} \mathrm{C} \cdot \mathrm{min}^{-1}$ to $270^{\circ} \mathrm{C}(5 \mathrm{~min})$, heating at $10^{\circ} \mathrm{C} \cdot \mathrm{min}^{-1}$ to $300^{\circ} \mathrm{C}$ (3 $\mathrm{min}$ ). Signal registration was performed using total ion current (TIC) in a scanning region of $35-650 \mathrm{~m} / \mathrm{z}$.

Prior to analysis, fatty acids were transformed into the corresponding methyl ethers (FAME). For this purpose, fatty acids were boiled in methanol with a catalytic amount of sulphuric acid and were hexane-extracted 3 times. The extract was then boiled down. A sample of FAME was dissolved in $10 \mathrm{ml}$ of hexane. An internal standard (ethyl butyrate) of a known concentration was added and analyzed.

High performance liquid chromatography with high resolution mass-spectrometric detection under electrospray ionization (HPLC-HRMS-ESI) in combination with UV detection was used to determine aminotriazoles. The device consisted of liquid 
chromatograph-Agilent 1269 Infinity and time-of-flight high resolution mass detectorAgilent 6230 TOF LC/MS (Agilent Technologies, Santa Clara, CA, USA). Block ionization was double electrospray, detection mass range was from 50 to 2000 Dalton (positive ions mode). Capillary voltage was $4.0 \mathrm{kV}$, fragmentor+191 V, skimmer+66 V, OctRF $750 \mathrm{~V}$. Column Zorbax Extend-C18 (Rapid Resolution HT $2.1 \times 50 \mathrm{~mm} ; 1.8 \mu \mathrm{m}$ ) was used. Gradient eluation: acetonitrile/water $\left(0.1 \%\right.$ formic acid); flow rate: $0.4 \mathrm{~mL} \cdot \mathrm{min}^{-1}$. Software for collection and elaboration of research results was MassHunter Workstation/Data Acquisition V.06.00.

Quantitative determination of aminotriazoles was carried out by an internal standard method. The calculated correction coefficients were within $1.000 \pm 0.010$ and were assumed equal to 1. A sample of aminotriazoles was dissolved in the mixture $(\mathrm{ACN}: \mathrm{MeOH}=1: 1)$ and the internal standard (3-pentyl-1H-1,2,4-triazol-5-amine) of a known concentration was added. Then it was analyzed.

Synthesis of 3-alkyl-5-amino-1H-1,2,4-triazoles in xylene (compound A)

The synthesis was conducted in a stirred tank reactor equipped with a water trap with a reflux condenser. While stirring, $1 \mathrm{~mol}(136.1 \mathrm{~g})$ of aminoguanidine bicarbonate was added to $700 \mathrm{ml}$ of xylene followed by $1 \mathrm{~mol}(280 \mathrm{~g})$ of a mixture of fatty acids. While stirring, the mixture was gradually heated, not exceeding $90-95^{\circ} \mathrm{C}$, till carbon dioxide stopped emitting. Then, the mixture was boiled for four hours with water collected in a trap (lower layer). At the end of this period, water separation stopped. The mixture was cooled down to $95^{\circ} \mathrm{C}$ with most xylene removed under reduced pressure. At the end of removal, the vacuum was increased to $20 \mathrm{mbar}$ to keep the temperature of the mixture within $90-95^{\circ} \mathrm{C}$ (this temperature ensured good mobility of the mixture). The vacuum was switched off and the hot product was poured out of the reaction vessel.

The composition of the compound $A$ according to GC-MS and HPLC-MS analysis is given in Table 1. The acid index was $54.6 \mathrm{mg} \mathrm{KOH} / \mathrm{g}$. The yield was $272 \mathrm{~g} \mathrm{(90 \% ).}$

${ }^{1} \mathrm{H}-\mathrm{NMR}$ (DMSO-d $\left.{ }_{6}\right), \delta(\mathrm{ppm}): 0.83-0.87\left(\mathrm{CH}_{3 \mathrm{alkyl}}\right), 1.22-1.26\left(\mathrm{CH}_{2 \mathrm{alkyl}}\right), 1.43-1.53$ $\left(\beta \mathrm{CH}_{2 \text { alkyl }}\right), \quad 1.92-2.05 \quad\left(\underline{\mathrm{CH}}_{2} \mathrm{CH}=\mathrm{CH}_{\text {alkyl }}\right), \quad 2.17-2.32 \quad\left(\alpha \mathrm{CH}_{2 \text { alkyl }}\right), \quad 2.71-2.76$ $\left(\mathrm{CH}=\mathrm{CHCH}_{2} \mathrm{CH}=\mathrm{CH}_{\text {alkyl }}\right), 5.27-5.47\left(\mathrm{CH}=\mathrm{CH}_{\text {alkyl }}\right), 5.45\left(\mathrm{NH}_{2}\right), 11.80(\mathrm{NH})$.

Synthesis of 3-alkyl-5-amino-1H-1,2,4-triazoles in toluene (compound B)

The synthesis was identical. However, the heating time was 8 hours. The composition of the compound $B$ according to GC-MS and HPLC-MS analysis is given in Table 1. Acid index was $50.6 \mathrm{mg} \mathrm{KOH} / \mathrm{g}$. The yield was $272 \mathrm{~g}(92 \%)$.

${ }^{1} \mathrm{H}-\mathrm{NMR}\left(\mathrm{DMSO}-\mathrm{d}_{6}\right), \delta(\mathrm{ppm}): 0.83-0.87\left(\mathrm{CH}_{3 \text { alkyl }}\right), 1.22-1.32\left(\mathrm{CH}_{\text {2alkyl }}\right), 1.48-1.56$ $\left(\beta \mathrm{CH}_{2 \text { alkyl }}\right), \quad 1.97-2.04 \quad\left(\underline{\mathrm{CH}}_{2} \mathrm{CH}=\mathrm{CH}_{\text {alkyl }}\right), \quad 2.16-2.38 \quad\left(\alpha \mathrm{CH}_{2 \text { alkyl }}\right), \quad 2.72-2.78$ $\left(\mathrm{CH}=\mathrm{CHCH}_{2} \mathrm{CH}=\mathrm{CH}_{\text {alkyl }}\right), 5.27-5.38\left(\mathrm{CH}=\mathrm{CH}_{\text {alkyl }}\right), 5.47\left(\mathrm{NH}_{2}\right), 11.80(\mathrm{NH})$. 
Synthesis of 3-alkyl-5-amino-1H-1,2,4-triazoles in butanol (compound C)

The synthesis was conducted in a stirred tank reactor equipped with a water trap with a reflux condenser. While stirring, $1 \mathrm{~mol}(136.1 \mathrm{~g})$ of aminoguanidine bicarbonate was added to $600 \mathrm{ml}$ of butanol followed by $280 \mathrm{~g}$ of a mixture of fatty acids. While stirring, the mixture was gradually heated not exceeding $90-95^{\circ} \mathrm{C}$ till carbon dioxide stopped emitting (visually till the foaming process was over). Then, the mixture was boiled for six hours with water collected in the trap (lower layer). The mixture was cooled down till the reaction mass stopped boiling. The water trap was replaced by a Wurtz tube with a thermometer and a descending condenser and butanol was removed at atmospheric pressure. Butanol removal was stopped when the mixture temperature reached $178^{\circ} \mathrm{C}$. Then the mixture was cooled down to $90^{\circ} \mathrm{C}$ and poured out.

The composition of the compound $C$ according to GC-MS and HPLC-MS analysis is given in Table 1. Acid index was $38.5 \mathrm{mg} \mathrm{KOH} / \mathrm{g}$.

The yield was $292 \mathrm{~g}(95 \%)$.

${ }^{1} \mathrm{H}-\mathrm{NMR} \quad\left(\mathrm{DMSO}-\mathrm{d}_{6}\right), \quad \delta \quad(\mathrm{ppm}): \quad 0.83-0.90 \quad\left(\mathrm{CH}_{3 a \mathrm{klky}}+\mathrm{CH}_{3 \text { butyl }}\right), \quad 1.23-1.34$ $\left(\mathrm{CH}_{2 \text { alkyl }}+\mathrm{CH}_{2 \text { butyl }}\right), \quad 1.43-1.56 \quad\left(\beta \mathrm{CH}_{2 \text { alkyl }}\right), \quad 1.96-2.08 \quad\left(\mathrm{CH}_{2} \mathrm{CH}=\mathrm{CH}_{\text {alkyl }}\right), \quad 2.26-2.39$ $\left(\alpha \mathrm{CH}_{2 \text { alkyl }}+\beta \mathrm{CH}_{2 \text { butyl }}\right), 2.72-2.75\left(\mathrm{CH}=\mathrm{CHCH}_{2} \mathrm{CH}=\mathrm{CH}_{\text {alkyl }}\right), 3.98-4.01\left(\alpha \mathrm{CH}_{2 \text { butyl }}\right) 5.27-$ $5.37\left(\mathrm{CH}=\mathrm{CH}_{\text {alkyl }}\right), 5.44\left(\mathrm{NH}_{2}\right), 11.80(\mathrm{NH})$.

\section{Corrosion inhibition measurements}

To evaluate protective effect of the synthesized compounds $(A-C)$, a set of electrochemical and full-scale corrosion methods was used and metallic surface analysis was carried out.

Potentiodynamic Polarization Measurements were performed at room temperature $\left(\sim 25^{\circ} \mathrm{C}\right)$ on copper M1 electrodes $(\mathrm{Cu}$ content not less than $99.9 \%)$ in an unstirred borate buffer water solution ( $\mathrm{pH}$ 7.4) with natural aeration, in the presence of the inhibitor and $10 \mathrm{mM} \mathrm{NaCl}$. A classical electrolytic three-electrode cell with unseparated electrode spaces was used in order to accelerate transient measurements.

Saturated silver chloride reference electrode was placed in a separate container connected to the electrolytic cell by an agar-agar based salt bridge filled with potassium nitrate saturated solution. The auxiliary electrode was a platinum grid. The working copper electrode was polished by K3000 sandpaper, degreased in 96\% ethanol, and washed with distilled water. The potentials of the working electrode $(E)$ are given according to the standard hydrogen electrode (SHE) scale. The current density $(i)$ was calculated by dividing the actual current $(I)$ by the geometric area of the working electrode $\left(0.75 \mathrm{~cm}^{2}\right)$.

Electrochemical measurements were performed using IPC-PRO potentiostat. In order to remove the oxide film appearing in air, the working $\mathrm{Cu}$-electrode was polarized at $E=-0.60 \mathrm{~V}$ for 15 minutes prior to the experiment. The electrode was then held in the solution for about 3 to 5 minutes until the stable free corrosion potential $\left(E_{\mathrm{cor}}\right)$ established. The working solution was then mixed with a $\mathrm{NaCl}$ solution while stirring, so that the concentration of chloride ions would be $C_{\mathrm{Cl}^{-}}=10 \mathrm{mM}$. The studied inhibitors were also 
added to the solution in the concentration of $C_{\text {inh }}=0.01,0.10$ and $1.00 \mathrm{mM}$. After the new $E_{\text {cor }}$ value was established, the $I, E$ polarization curve was registered by scanning the potential towards either the anodic or the cathodic direction at $0.2 \mathrm{mV} / \mathrm{sec}$. Pitting potential $\left(E_{\mathrm{pit}}\right)$ was identified by the rapid increase in the current on the anodic polarization curve. Pits were then visually identified on the surface of the electrode. The measurement error for $E_{\text {pit }}$ was below $0.03 \mathrm{~V}$.

The rate of corrosion in current units $\left(i_{\mathrm{cor}}\right)$ was determined by the polarization resistance technique as summarized by Mansfeld [34].

The effectiveness of the inhibition activity of the 3-alkyl-5-amino- $1 H-1,2,4$-triazole $(A-C)$ was evaluated judging by the protection level

$$
Z_{\mathrm{i}}=\frac{i_{\mathrm{cor}, 0}-i_{\text {cor,inh }}}{i_{\text {cor }, 0}} \cdot 100 \%
$$

where $i_{\mathrm{cor}, 0}$ and $i_{\mathrm{cor}, \text { inh }}$ are the corrosion current density with and without the inhibitor respectively.

The electrochemical impedance spectroscopy (EIS) was performed using the IPC-PRO potentiostat with a frequency response analyser FRA-2. After $E_{\text {cor }}$ was stable for 30 minutes, the frequency dependent impedance was registered within the range from 0.1 to $5.000 \mathrm{~Hz}$ with no current. The results were presented as a Nyquist diagram. The analysis of the obtained results, the selection of the equivalent circuit, and determining its component values was carried out using DCS software.

The inhibition efficiency was calculated from the equation:

$$
\eta_{\text {inh }}=\left(1-\frac{R_{\mathrm{p}, 0}^{\mathrm{EIS}}}{R_{\mathrm{p}, \mathrm{inh}}^{\mathrm{EIS}}}\right) \cdot 100 \%,
$$

where $R_{\mathrm{p}, 0}^{\mathrm{EIS}}$-is charge transfer resistance without the inhibitor and $R_{\mathrm{p}, \text { inh }}^{\mathrm{EIS}}-$ with the inhibitor.

For scanning electron microscopy (SEM) of the surface, a Jeol JSM-680LV scanning electron microscope (Japan) was used together with Oxford Instrument INCA 250 X-ray microanalysis module (UK) which determines the chemical composition of the surface layer.

The Natural Corrosion Test were carried out on copper plates with the surface area $S=20 \times 50 \mathrm{~mm}^{2}$ and the thickness $d=0.10 \mathrm{~mm}$, which were previously polished by $\mathrm{K} 3000$ sandpaper and degreased in acetone. The protective inhibitor films were obtained by holding the copper plates in a water solution with the inhibitor for 60 minutes at $60^{\circ} \mathrm{C}$.

Experiments which lasted $t=7$ days were carried out simultaneously on three samples in the unstirred naturally aerated $1 \% \mathrm{HCl}$ water solution. After the experiments, the plates were washed off with distilled water and treated with the requirements of GOST 9.907-83 "Methods of products disposal after corrosion testing". The rate of corrosion was determined by the samples' weight loss and calculated from the equation: 


$$
k=\frac{m_{0}-m}{S \cdot t} \cdot 100 \%,
$$

where $m_{0}$ and $m$ are sample weight before and after the corrosion testing respectively.

The inhibition efficiency of 3-alkyl-5-amino- $1 H$-1,2,4-triazole was evaluated by the value of inhibition coefficient:

$$
\gamma=\frac{k_{0}}{k_{\text {inh }}},
$$

and the degree of protection:

$$
Z_{\mathrm{k}}=\frac{k_{0}-k_{i n h}}{k_{0}} \cdot 100 \%,
$$

where $k_{0}$ and $k_{\text {inh }}$ are the rate of corrosion in $\mathrm{HCl}$ solution with inhibitor and without inhibitor respectively. The parameter $k_{0}$ was $20 \mathrm{~g} \cdot \mathrm{m}^{-2} \cdot \mathrm{day}^{-1}$.

Atmospheric corrosion of copper was accelerated by means of salt spray testing in order to determine the inhibition effect of 3-aklyl-5-amino- $1 H$-1,2,4-triazole for inter-operational protection of copper products. The samples were dried and placed in the cabin at 95-100\% air humidity. A 5\% solution of $\mathrm{NaCl}(\mathrm{pH}$ 6.5-7.2, GOST R 52763-2007) was sprayed into the cabin every hour. The samples were examined 3 times every 24 hours in order to register the moment $\left(\tau_{\text {cor }}\right)$ of appearence of first signs of corrosion attack.

The inhibition effect was studied on systems with the inhibitor concentration of 0.01 , 0.10 , and $1.00 \mathrm{mM}$. Due to low solubility of the substances in water solutions, they were dissolved in 1,4-dioxane prior to the experiment. During electrochemical measurements, the solution of inhibitors dissolved in 1,4-dioxane was added directly to chloride buffer. In case of full-scale corrosion testing, the required concentrations were obtained by 2,4-dioxane dilution without water.

\section{Results and Discussion}

\section{Characterization of compounds}

Sunflower oil processing waste, i.e. a mixture of fatty acids consisting primarily of palmitic, stearic, olenic, linolic, and linolenic acids, was used to synthesise 3-alkyl-5-amino-1,2,4triazoles. 3-Alkyl-5-amino-1,2,4-triazoles were prepared from fatty acids by a known procedure [35-37] (Figure 1). At the first stage, the interaction with aminoguanidine carboxylic acid led to the formation of substituted hydrazides of fatty acids which underwent intermolecular cyclization resulting in the elimination of water molecules and the formation of 3-alkyl-5-amino-1H-1,2,4-triazoles. The reaction was carried out under different conditions: by boiling in xylene, toluene, and butanol. It is probable that low electrophilicity of carbonyl carbon atom of fatty acids caused incomplete conversion of initial reagents. The 
data of GC-MS and HPLC-MS analysis was used to determine the structure of products formed as a result of the reaction carried out in different conditions (Table 1).

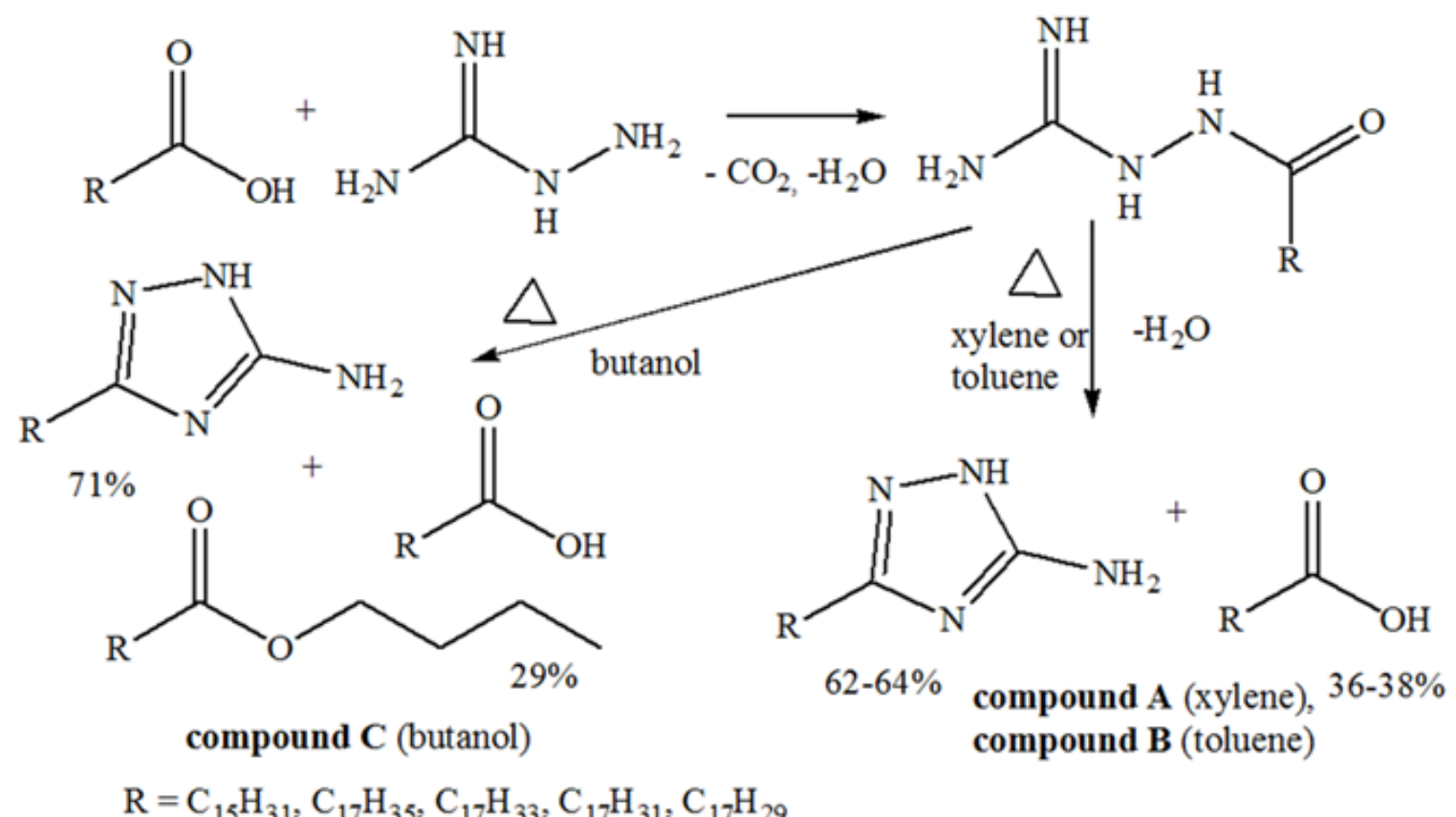

Figure 1. The scheme of synthesis of 3-alkyl-5-amino-1H-1,2,4-triazoles from fatty acids.

Table 1. The composition of the mixture of fatty acids and products. ${ }^{1}$

\begin{tabular}{|c|c|c|c|c|c|c|c|}
\hline \multirow{2}{*}{$\begin{array}{l}\text { Type of } \\
\text { fatty acid }\end{array}$} & \multirow{2}{*}{$\begin{array}{c}\begin{array}{c}\text { Mixture of } \\
\text { fatty acids } \\
\text { of sunflower } \\
\text { oil }\end{array} \\
\begin{array}{c}\text { Fatty acid } \\
\text { content, } \\
\%\end{array}\end{array}$} & \multicolumn{2}{|c|}{$\begin{array}{c}\text { Compound } A \\
\text { (Xylene) }\end{array}$} & \multicolumn{2}{|c|}{$\begin{array}{c}\text { Compound } B \\
\text { (Toluene) }\end{array}$} & \multicolumn{2}{|c|}{$\begin{array}{c}\text { Compound } C \\
\text { (Butanol) }\end{array}$} \\
\hline & & $\begin{array}{c}\text { Triazole } \\
\text { content, } \\
\%\end{array}$ & $\begin{array}{c}\text { Fatty acid } \\
\text { content, } \\
\%\end{array}$ & $\begin{array}{c}\text { Triazole } \\
\text { content, } \\
\%\end{array}$ & $\begin{array}{c}\text { Fatty } \\
\text { acid } \\
\text { content, } \\
\%\end{array}$ & $\begin{array}{c}\text { Triazole } \\
\text { content, } \\
\%\end{array}$ & $\begin{array}{c}\text { Fatty } \\
\text { acid } \\
\text { content, } \\
\%\end{array}$ \\
\hline total & 100 & 64 & 36 & 62 & 38 & 71 & 29 \\
\hline $\mathrm{C} 16$ & 11.5 & 6.5 & 4.1 & 5.4 & 4.4 & 5.9 & 3.2 \\
\hline $\mathrm{C} 18$ & 5.5 & 4.0 & 1.9 & 2.8 & 2.0 & 2.8 & 1.5 \\
\hline C18:1 (9) & 37.5 & 23.1 & 13.8 & 19.1 & 14.4 & 27.7 & 11.0 \\
\hline $\begin{array}{l}\text { C18:2 } \\
(9,12)\end{array}$ & 43.0 & 29.0 & 15.5 & 29.3 & 16.4 & 32.9 & 12.7 \\
\hline $\begin{array}{c}\mathrm{C} 18: 3 \\
(9,12,15)\end{array}$ & 2.5 & 1.4 & 0.7 & 5.4 & 0.8 & 1.7 & 0.6 \\
\hline
\end{tabular}


${ }^{1}$ The table presents the main ingredients of the mixture with content over $1 \%$.

For example, products prepared as a result of boiling in toluene and xylene had up to $68 \%$ of 3-alkyl-5-amino- $1 H-1,2,4$-triazoles and up to $38 \%$ of free fatty acids. These data were proved by the values of the acid index. These solvents are disadvantageous as in the process of synthesis they need to be removed by a strong vacuum. The structure of products was also proved by NMR ${ }^{1} \mathrm{H}$ spectroscopy. The spectra had classifying signals of: methyl group multiplet at $0.83-0.90 \mathrm{ppm}, \mathrm{CH}_{2}$-groups multiplet at $1.22-1.34 \mathrm{ppm}$., $\beta_{\mathrm{CH}_{2} \text {-group }}$ multiplet at $1.43-1.56 \mathrm{ppm}$, a set of $\mathrm{CH}_{2}$ multiplets adjacent to heterocycle and multiple bonds at 1.92-2.08 and 2.16-2.39 ppm. Also, $\mathrm{CH}_{2}$-groups multiplet of linolic and linolenic acids could be seen in the region of $2.71-2.78 \mathrm{ppm}$ and a multiplet of olefinic protons at 5.27-5.47. Broad singlets of endo- and exocyclic amino groups could be seen at 11.80 and 5.44-5.47 ppm respectively.

The product prepared in butanol had $71 \%$ of 3-alkyl-5-amino- $1 H-1,2,4$-triazoles and $29 \%$ of a mixture of fatty acids and butyl ethers of fatty acids. It means that when the reaction is carried out in butanol the process is accompanied by esterification of fatty acids with butanol which leads to a decrease in acid index. NMR ${ }^{1} \mathrm{H}$ spectroscopy revealed butyl ethers of fatty acids present in the product $C$. The spectrum contained proton signals of a butyl unit, including $\mathrm{OCH}_{2}$-group triplet in the region of $4.00 \mathrm{ppm}$. A reaction in butanol does not require a vacuum to remove the solvent which makes this approach easier to scale. Lower fatty acids content leads to improved anti-corrosion properties which will be described hereinafter.

\section{Corrosion inhibition measurements}

The results of measurements of $E_{\text {cor }}$ of copper electrode in a neutral chloride solution in presence of 3-alkyl-5-amino-1H-1,2,4-triazoles are given in Table 2. At the additive's concentration of $C_{\text {inh }}=0.01-0.10 \mathrm{mM}, E_{\text {cor }}$ shifted towards positive values. The maximum difference of up to $30-40 \mathrm{mV}$ was obtained for the solution with the compound $A .0 .01 \mathrm{mM}$ solution with the compound $B$ made an exclusion. According to [38], the synthesized substances can be classified as inhibitors of a mixed type which primarily control anode reaction. With the most studied concentration of $1.00 \mathrm{mM}$, a shift of $E_{\text {cor }}$ was recorded towards negative values of up to $100 \mathrm{mV}$ as compared to the control values. When the discussed concentration was reached, a clouding within the solution could be visually identified. This was obviously due to the exceeded value of the maximum solubility in water solutions.

The polarization curves of copper in neutral chloride solutions, with the inhibitors under consideration, are given in Figure 2. We can see that when the anodic polarization is low, the current density for all 3-alkyl-5-amino- $1 H$-1,2,4-triazoles of $A-C$ with a concentration of $0.01-0.10 \mathrm{mM}$ is lower than in the solution without the inhibitors. The anodic maximum was only identified for the compounds $B$ and $C$ and the anodic current density exceeded the control value. Value $E_{\text {pit }}$ for the substances under consideration did not exceed the control value. 
The difference between cathodic curves of copper in solutions with, and without inhibitors is insignificant: $C_{\text {inh }}=0.01-0.10 \mathrm{mM}$. Lower current density values were obtained for the compound $C: C_{\text {inh }}=0.01 \mathrm{mM}$, (Figure $2 \mathrm{c}$, curves $2^{\prime}$ ). At a concentration of $C_{\mathrm{inh}}=1.00 \mathrm{mM}$, cathodic polarization curve was characterised by a more intensive growth of the current density as compared to that of the control test (Figure $2 \mathrm{a}-\mathrm{c}$, curves $4^{\prime}$ ).

Analysis of the polarization resistance, $R_{\mathrm{p}}$, the rate of corrosion, and the degree of protection (Table 2) revealed relatively low protective properties of the prepared compounds in neutral water solutions in presence of chlorides. The compound $A$ at $C_{\mathrm{inh}}=0.01 \mathrm{mM}$ and the compound $C$ at $C_{\text {inh }}=0.01-0.10 \mathrm{mM}$ can be considered to be more efficient. With a concentration of $C_{\mathrm{inh}}=1.00 \mathrm{mM}$, the rate of corrosion increased, whereas the value $R_{\mathrm{p}}$ remained low.

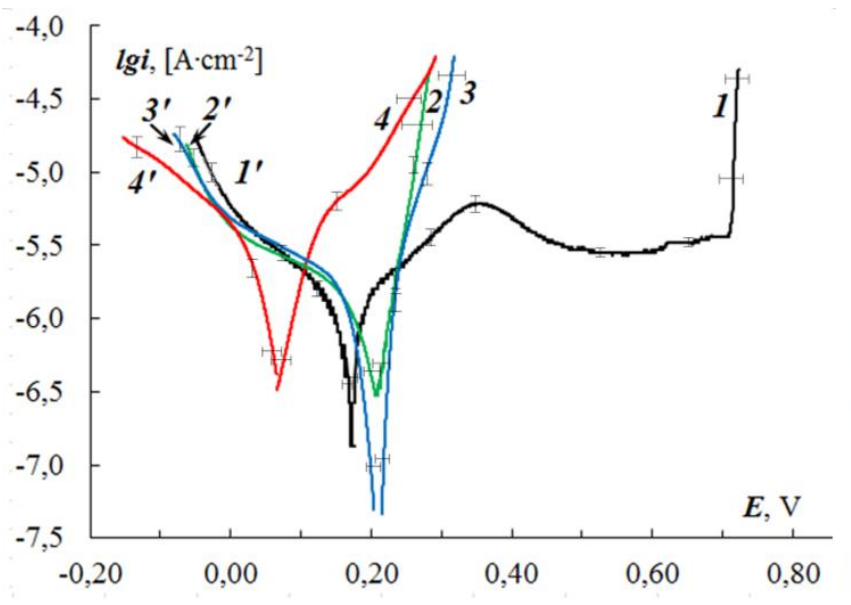

(a)

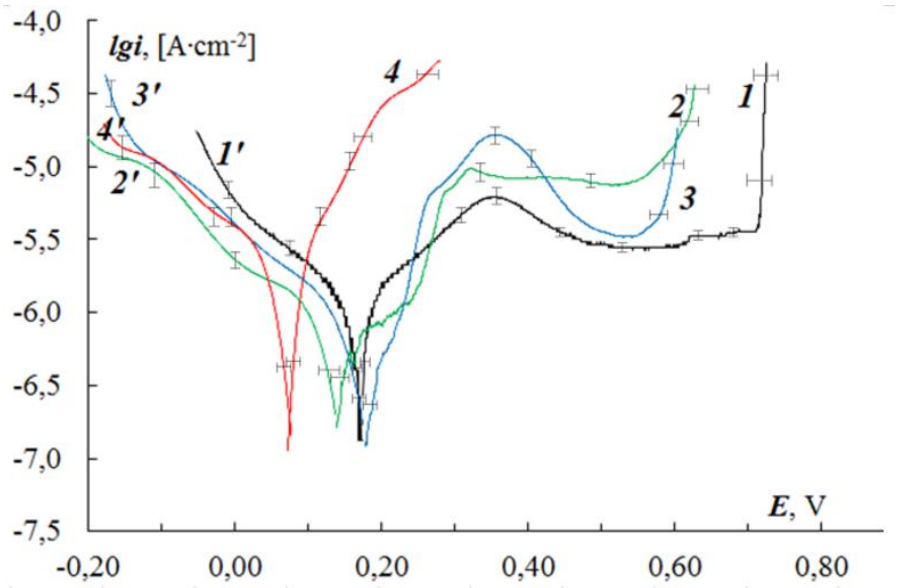

(b)

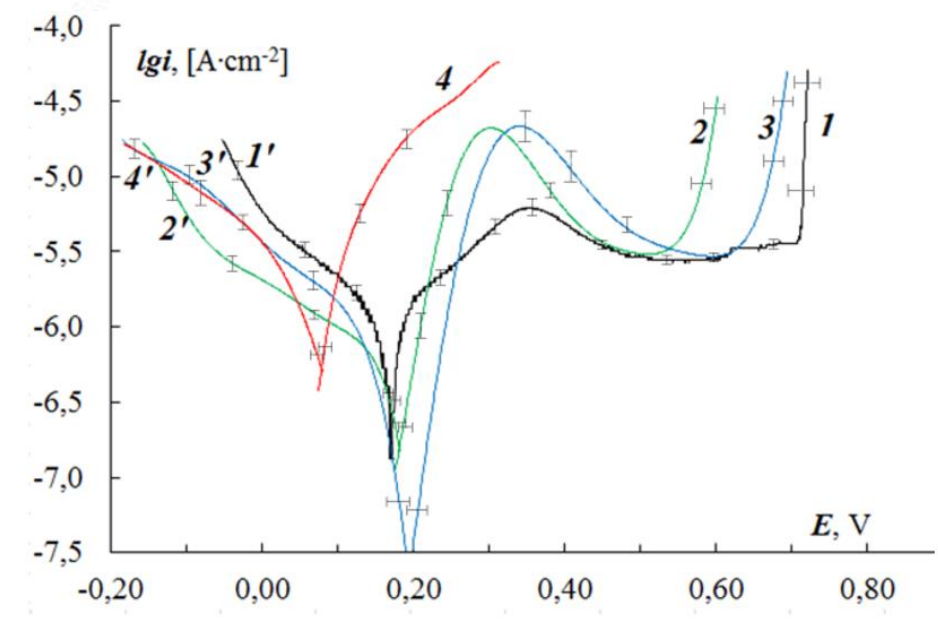

(c)

Figure 2. Anodic (1-4) and cathodic $\left(1^{\prime}-4^{\prime}\right)$ polarization curves of copper in a borate buffer (pH 7.4) with $10.0 \mathrm{mM} \mathrm{NaCl}$ and compound $A$ (a), compound $B(\mathrm{~b})$, compound $C$ (c) at the following concentrations: $1,1^{\prime}-0.00 \mathrm{mM} ; 2,2^{\prime}-0.01 \mathrm{mM} ; 3,3^{\prime}-0.10 \mathrm{mM} ; 4,4^{\prime}-1.00 \mathrm{mM}$. 
Table 2. Open circuit potential $E_{\mathrm{cor}}$, polarization resistance $R_{\mathrm{p}}$, corrosion current density $i_{\text {cor }}$, and degree of protection of copper $Z_{i}$, in $10 \mathrm{mM} \mathrm{NaCl}$ solutions with 3-alkyl-5-amino-1H-1,2,4-triazole.

\begin{tabular}{cccccc}
\hline Inhibitor & $\boldsymbol{C}_{\mathbf{i n h}}, \mathbf{m M}$ & $\boldsymbol{E}_{\mathbf{c o r}}, \mathbf{V}$ & $\boldsymbol{R}_{\mathbf{p}}, \mathbf{k} \boldsymbol{\mathbf { \Omega } \cdot \mathbf { c m } ^ { \mathbf { 2 } }}$ & $\boldsymbol{i}_{\mathbf{c o r}}, \boldsymbol{\mu} \mathbf{A} \cdot \mathbf{c m}^{-\mathbf{2}}$ & $\boldsymbol{Z}_{\mathbf{i}}, \boldsymbol{\%}$ \\
\hline- & - & 0.172 & $41.6 \pm 4.6$ & $1.2 \pm 0.3$ & - \\
\hline Compound $A$ & 0.01 & 0.208 & $45.5 \pm 9.7$ & $0.5 \pm 0.1$ & 58 \\
(Xylene) & 0.10 & 0.211 & $38.1 \pm 5.8$ & $1.1 \pm 0.3$ & 8 \\
& 1.00 & 0.068 & $15.2 \pm 0.8$ & $1.7 \pm 0.4$ & -42 \\
\hline \multirow{2}{*}{ Compound $B$} & 0.01 & 0.139 & $33.1 \pm 6.6$ & $1.2 \pm 0.3$ & 0 \\
(Toluene) & 0.10 & 0.181 & $39.1 \pm 3.9$ & $1.1 \pm 0.2$ & 8 \\
& 1.00 & 0.076 & $12.4 \pm 2.1$ & $6.2 \pm 0.8$ & -417 \\
\hline \multirow{2}{*}{ Compound $C$} & 0.01 & 0.183 & $43.2 \pm 6.7$ & $0.61 \pm 0.15$ & 49 \\
(Butanol) & 0.10 & 0.195 & $35.4 \pm 5.9$ & $0.58 \pm 0.12$ & 52 \\
& 1.00 & 0.081 & $15.2 \pm 1.6$ & $2.3 \pm 0.5$ & -92 \\
\hline
\end{tabular}

Similar results were obtained by EIS method. Figure 3 presents Nyquist diagrams obtained for the chloride-borate solution with and without the $A, B$, and $C$ inhibitors with the concentrations of $C_{\mathrm{inh}}=0.01-1.00 \mathrm{mM}$. The hodographs for similar concentrations are identical. Consequently, identical functions were combined. Compound $C$, with a concentration of $C_{\mathrm{inh}}=0.01 \mathrm{mM}$, was an exception.

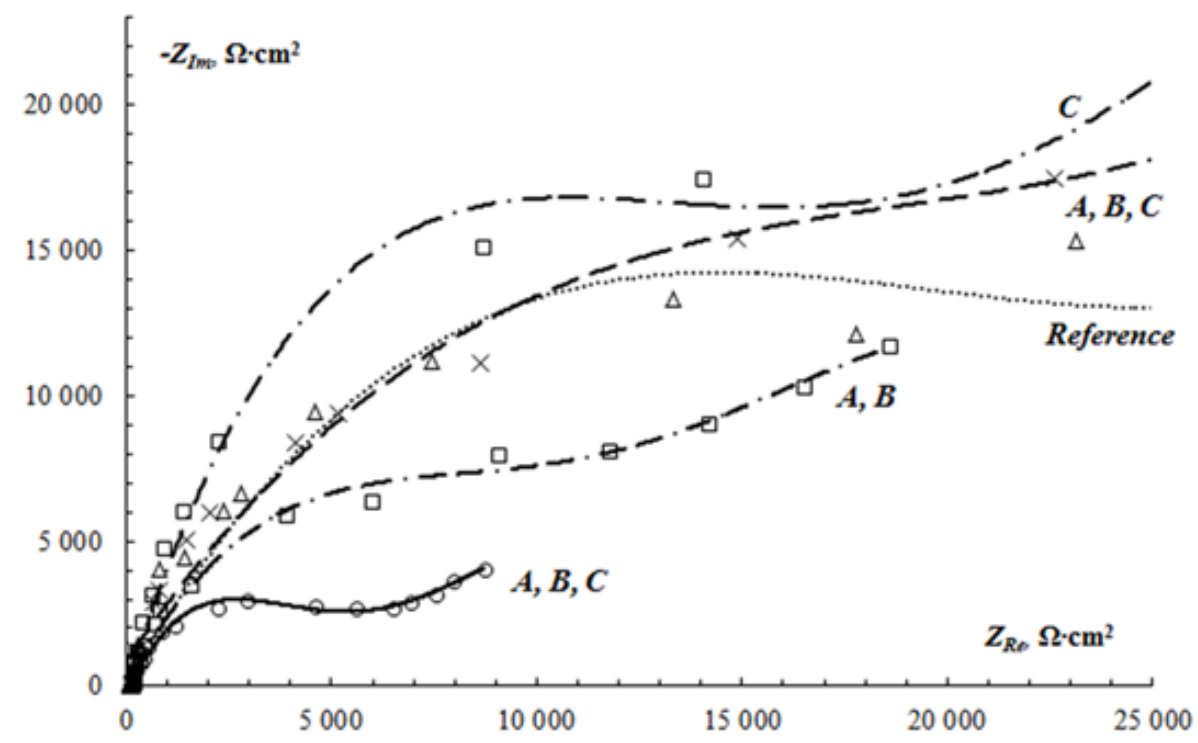

Figure 3. The Nyquist diagrams of copper in borate buffer $(\mathrm{pH} 7.4)+10 \mathrm{mM} \mathrm{NaCl}$ without an inhibitor (reference), in the presence of compound $A(\mathrm{~A})$, compound $B(\mathrm{~B})$, compound $C(\mathrm{C})$ at concentrations of $0.01(-\cdot), 0.10(--)$, and $1.00 \mathrm{mM}(-)$. 
At high frequencies, the hodographs are presented as imperfect semi-circumferences, the imperfection being usually accounted for by the impedance frequency dispersion and the geometric and/or energetic inhomogeneity of the electrode's surface.

The regression analysis of the impedance spectroscopy data was used to determine the most probable equivalent circuit simulation of the processes at the copper/solution interface (Figure 4). Table 3 presents the values of the following circuit elements: $R_{\Omega}$ (ohmic resistance of the solution), $C_{\mathrm{DL}}$ (double-layer capacitance), $R_{\mathrm{p}}$ (polarization resistance of the electrochemical reaction), and $B W$ (Warburg impedance).

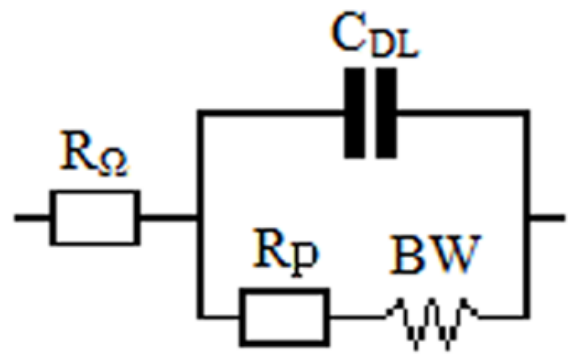

Figure 4. The EEC model used to fit the EIS response $\left(R_{\Omega}-\right.$ direct-current resistance, $C_{\mathrm{DL}}-$ double-layer capacitance, $R_{\mathrm{p}}$-polarization resistance of the electrochemical reaction, $B W-$ Warburg impedance).

Table 3. Equivalent circuit elements and degree of protection of copper electrode in $10 \mathrm{mM} \mathrm{NaCl}$ solutions with 3-alkyl-5-amino-1H-1,2,4-triazole.

\begin{tabular}{|c|c|c|c|c|c|c|}
\hline Inhibitor & $C_{\mathrm{inh}}, \mathrm{mM}$ & $\begin{array}{c}R \Omega, \\
\Omega \cdot \mathrm{cm}^{2}\end{array}$ & $\begin{array}{c}C_{\mathrm{DL}}, \\
\mu \mathrm{F} \cdot \mathrm{cm}^{-2}\end{array}$ & $\begin{array}{c}R_{\mathrm{p}}^{\mathrm{EIS}} \\
\mathrm{k} \Omega \cdot \mathrm{cm}^{2}\end{array}$ & $\begin{array}{c}B W, \\
\mathrm{k} \Omega \cdot \mathrm{cm}^{2} \cdot \mathrm{s}^{-0.5}\end{array}$ & $\begin{array}{c}\text { Degree of } \\
\text { protection, } \\
\eta_{\text {inh }}, \%\end{array}$ \\
\hline- & 0.00 & 214 & 2.84 & 7.49 & 9.68 & - \\
\hline \multirow{3}{*}{$\begin{array}{c}\text { Compound } A \\
\text { (Xylene) }\end{array}$} & 0.01 & 165 & 3.99 & 9.94 & 12.09 & 20 \\
\hline & 0.10 & 155 & 2.69 & 17.36 & 24.89 & 61 \\
\hline & 1.00 & 170 & 9.82 & 5.37 & 3.45 & -181 \\
\hline \multirow{3}{*}{$\begin{array}{c}\text { Compound } B \\
\text { (Toluene) }\end{array}$} & 0.01 & 160 & 3.85 & 13.73 & 11.92 & 19 \\
\hline & 0.10 & 175 & 2.00 & 19.48 & 22.26 & 57 \\
\hline & 1.00 & 170 & 7.89 & 5.12 & 2.41 & -302 \\
\hline \multirow{3}{*}{$\begin{array}{c}\text { Compound C } \\
\text { (Butanol) }\end{array}$} & 0.01 & 155 & 1.51 & 23.74 & 40.75 & 76 \\
\hline & 0.10 & 155 & 2.61 & 26.50 & 16.15 & 40 \\
\hline & 1.00 & 165 & 8.31 & 5.08 & 3.07 & -215 \\
\hline
\end{tabular}

$R_{\mathrm{p}}^{\mathrm{EIS}}$ at $C_{\mathrm{inh}}=0.01-1.00 \mathrm{mM}$ exceeded the results of the control test without additive for all substances under consideration (Table 3). This is indicative of a protective effect. 
Further evidence is that the Warburg impedance grew rapidly when inhibitors were added to the solution. This meant either that the diffusion of the soluble corrosion product on the electrode's surface slowed down, or that the barrier properties of the protective film blocking the aggressive elements of the solution increased.

At $C_{\mathrm{inh}}=1.00 \mathrm{mM}$, there was an increase in $C_{\mathrm{DL}}$ and a decrease in $R_{\mathrm{p}}^{\mathrm{EIS}}$ and $B W$ for all structures, which normally leads to an increase in the rate of corrosion. An increase in $C_{\mathrm{DL}}$ is caused by an increase in local dielectric permittivity and/or a decrease in the thickness of the formed double-layer capacitance. A simultaneous change of parameters characterizing the charge transfer and diffusion indicate a mixed mechanism of corrosion control.

To explain the effect, we carried out scanning electron microscopy and analyzed the micrographs of the copper electrode surface taken before, and after, the anodic polarization in a neutral chloride solution. Figure 5 demonstrates that, without the inhibitors, multiple corrosion spots of about $10 \mu \mathrm{m}$ appear on the surface (Figure 5b). However, when the copper is polarized in the solution with $0.10 \mathrm{mM}$ of the compound $C$, no pits can be observed on the surface (Figure 5c). The micrographs show only scratches left from polishing the electrode. The electrode surface is identical to that before polarization (Figure 5a). With a concentration of $C_{\mathrm{inh}}=1.00 \mathrm{mM}$, no pits can be observed either (Figure 5d). However, there is an even development of the surface as compared to the electrode surface before polarization. It can possibly mean that uniform solubilization of copper is taking place.

The results of the analysis of the elemental composition of the surface layer of the copper electrode before and after anodic polarization are given in Table 4. Quite notably, the introduction of the organic additives results in a significant decrease in the amount of oxygen on the copper surface, which may be accounted for by the fact that the metal oxidation slows down due to the slowdown of the anodic process.

Table 4. Elemental surface composition (at. \%) of the copper electrode.

\begin{tabular}{ccc}
\hline Polarisation mode & \multicolumn{2}{c}{ Element } \\
\cline { 2 - 3 } No polarisation & Cu & O \\
\hline After polarisation in borate buffer+10 mM NaCl & 100.0 & 0.0 \\
After polarisation in borate buffer+10 $\mathrm{mM} \mathrm{NaCl}+0.10 \mathrm{mM}$ of compound $C$ & 93.1 & 6.9 \\
After polarisation in borate buffer+10 $\mathrm{mM} \mathrm{NaCl}+1.00 \mathrm{mM}$ of compound $C$ & 94.3 & 5.7 \\
\hline
\end{tabular}

The results of salt spray testing differed from the results of electrochemical testing in solutions (Table 5).

With the minimum concentration of $C_{\mathrm{inh}}=0.10 \mathrm{mM}$, the period when the first signs of corrosion appear, $\tau_{\text {cor }}$, is identical for all compounds. With an inhibitor concentration of $C_{\mathrm{inh}} \geq 0.10 \mathrm{mM}$, the protective effect changed as follows: compound $A<$ compound $B \approx$ 
compound $C . \tau_{\text {cor }}$ increased with a higher $C_{\text {inh }}$, and reached $4-6$ days at $1.00 \mathrm{mM}$, which proved the effectiveness of derivatives of 5-amino- $1 \mathrm{H}-1,2,4$-triazole for copper in moist atmosphere in presence of chlorides.

The analysis of the images of the surface of copper samples held in the salt spray cabin agrees well with the values of $\tau_{\text {cor }}$ (Figure 6 ). The images of the compound $B$ were made after the samples were held in the salt spray cabin for 12 hours. Samples of compounds $A$ and $C$ looked identical. They show that in presence of the inhibitor with the concentration of $C_{\text {inh }} \geq 0.10 \mathrm{mM}$ copper remains bright and smooth (Figure $5 \mathrm{~d}-\mathrm{e}$ ). Without the anticorrosion treatment, the surface darkens, and corrosion spots appear (Figure 5b). With a concentration of $C_{\text {inh }}=0.01 \mathrm{mM}$, the color of the surface slightly changed but it remained smooth (Figure 5c).

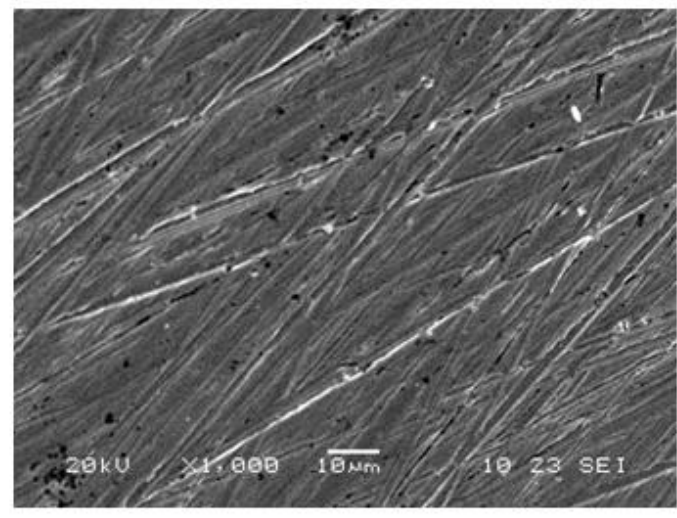

(a)

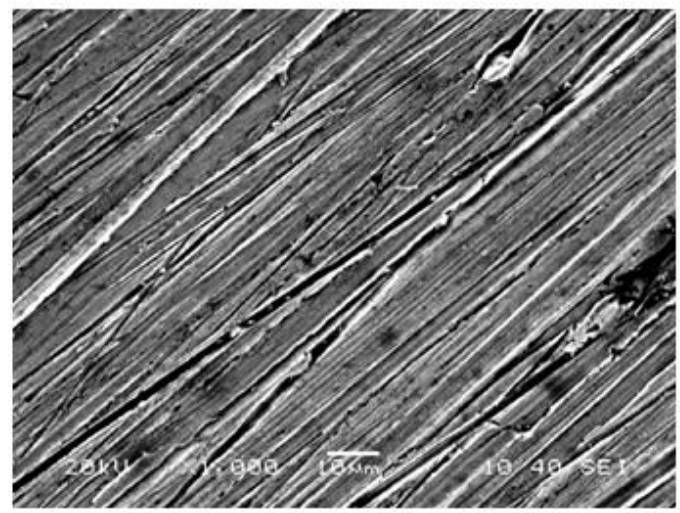

(c)

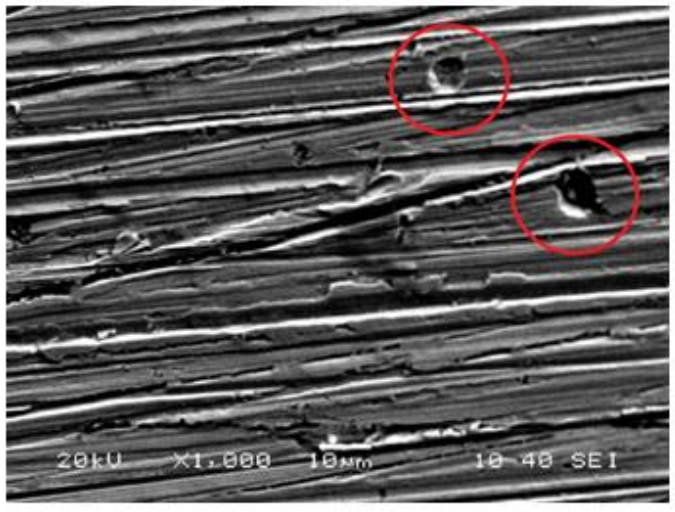

(b)

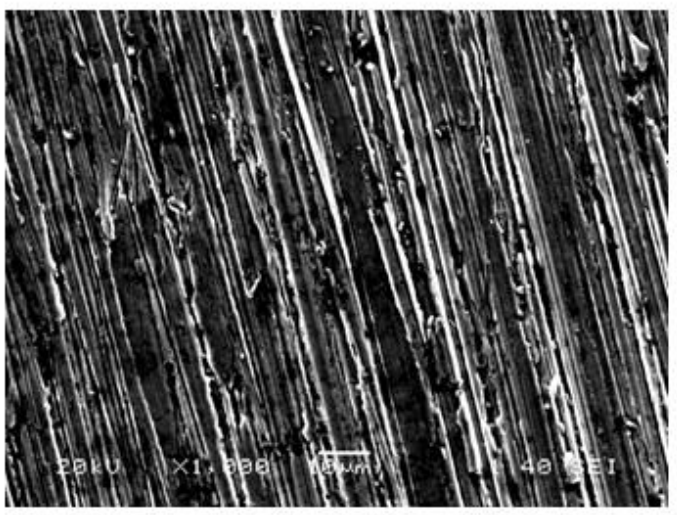

(d)

Figure 5. SEM micrographs of copper surface (a) before polarization, (b) after polarization in borate buffer $(\mathrm{pH} 7.4)+10 \mathrm{mM} \mathrm{NaCl}$, (c) after polarization in borate buffer $(\mathrm{pH} 7.4)+10 \mathrm{mM}$ $\mathrm{NaCl}+0.10 \mathrm{mM}$ of (compound $C$ ) and (d) $1.00 \mathrm{mM}$ of (compound $C$ ). 
Table 5. Results of the copper natural corrosion tests.

\begin{tabular}{cccccc}
\hline Inhibitor & $\boldsymbol{C}_{\mathbf{i n h}}, \mathbf{m M}$ & $\boldsymbol{k}, \mathbf{g} \cdot \mathbf{m}^{\mathbf{2}} \cdot \mathbf{d a y}$ & $\boldsymbol{\gamma}$ & $\boldsymbol{Z}_{\mathbf{k}}, \boldsymbol{\%}$ & $\boldsymbol{\tau}_{\mathbf{c o r}}, \mathbf{h}$ \\
\hline- & 0.00 & 20.0 & 1.0 & 0.0 & $1-2$ \\
\hline Compound $A$ & 0.01 & 17.5 & 1.1 & 12.5 & 24 \\
(Xylene) & 0.10 & 0.4 & 50.0 & 98.0 & 73 \\
& 1.00 & 0.2 & 100.0 & 99.0 & 101 \\
\hline Compound $B$ & 0.01 & 1.7 & 11.8 & 91.5 & 21 \\
(Toluene) & 0.10 & 0.3 & 66.7 & 98.5 & 98 \\
& 1.00 & 0.2 & 100.0 & 99.0 & 138 \\
\hline Compound $C$ & 0.01 & 0.9 & 22.2 & 95.5 & 24 \\
(Butanol) & 0.10 & 0.3 & 66.7 & 98.5 & 100 \\
& 1.00 & 0.2 & 100.0 & 99.0 & 139 \\
\hline
\end{tabular}

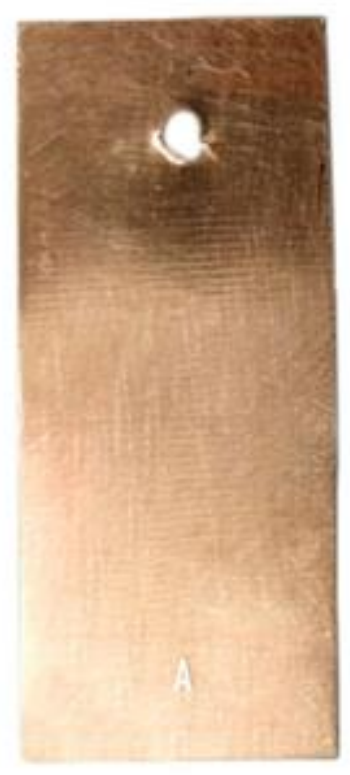

(a)

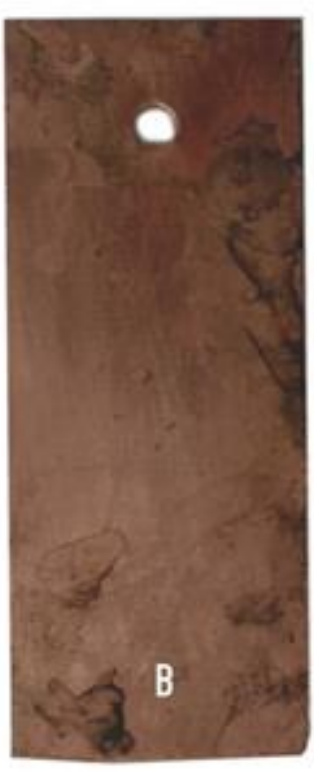

(b)

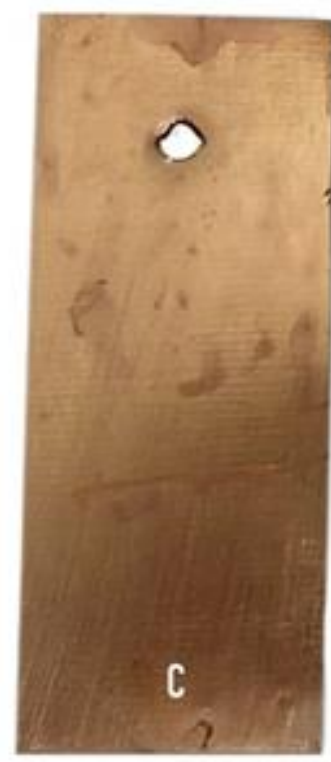

(c)

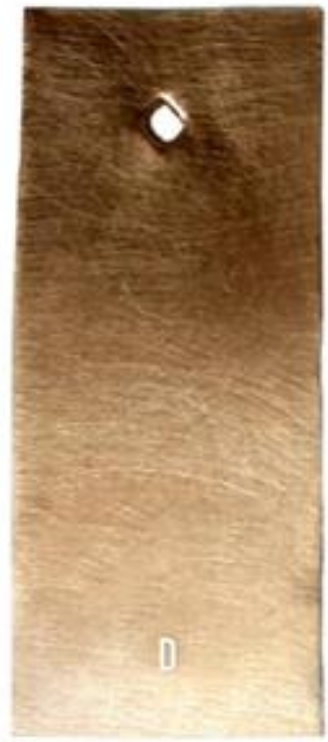

(d)

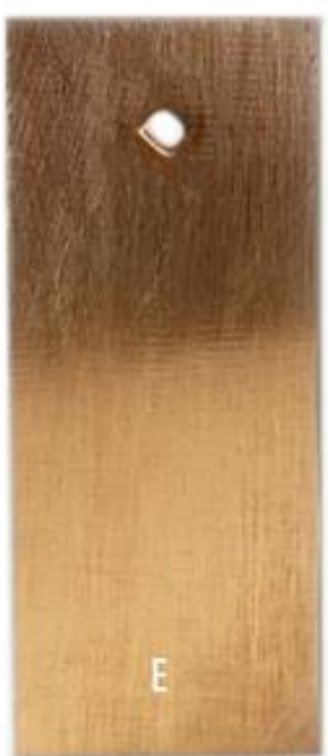

(e)

Figure 6. Copper samples before (a) and after salt spray corrosion testing without an inhibitor (b), and in the presence of compound $B$ at concentrations of 0.01 (c), 0.10 (d), $1.00 \mathrm{mM}$ (e).

We believe that the difference between electrochemical and full-scale corrosion tests is due to different conditions of preparing inhibitive layers on the copper surface. By comparing the experimental data, we can assume that 3-alkyl-5-amino-1 $\mathrm{H}$-1,2,4-triazoles are more effective after they are held in a non-aqueous solutions, based, for example, on 1,4 dioxane. It is less effective to add substances which were preliminary dissolved in an organic 
solvent. This is probably due to a low solubility of long-chain derivatives of 5-amino- $1 \mathrm{H}$ 1,2,4-triazole.

Table 5 presents the results of corrosion tests in an acid $\mathrm{HCl}$ environment. The degree of protection for all substances under consideration is over $90 \%$. The compound $A$ makes an exclusion at a concentration of $C_{\mathrm{inh}}=0.01 \mathrm{mM}$, where the rate of corrosion decreases by about $10 \%$. The highest protective effect of $Z_{\mathrm{k}}=98-99 \%$ was obtained at a concentration of $C_{\text {inh }}=0.10-1.00 \mathrm{mM}$.

\section{Conclusion}

3-Alkyl-5-amino-1H-1,2,4-triazoles were prepared from sunflower oil processing waste, mixtures of fatty acids, under different conditions. It was demonstrated that when a reaction is carried out in butanol, the content of triazoles in the product increases to $71 \%$. The process is accompanied by esterification of unreacted fatty acids with butanol.

It was shown that 3-alkyl-5-amino-1H-1,2,4-triazoles are effective copper corrosion inhibitors in neutral and acid chloride environments. The highest protective effect is when metal products are primarily held in a solution with a compound based on an organic solvent. The protective effect increases with the concentration and reaches $99 \%$ at $1.00 \mathrm{mM}$, when exposed to $\mathrm{HCl}$ solution. The period before the first signs of corrosion appear in a salt spray cabin increases by 60 times as compared to control testing and reaches $4-6$ days.

The protective effect deteriorates when substances are added directly to the solution. The highest protective effect of up to $50-75 \%$ is with a concentration of the additive of 0.01-1.00 mM. An increase in concentration up to $1.00 \mathrm{mM}$ intensifies the corrosion, which is probably due to inhibitor precipitation as a result of exceeding values of solubility in water solutions. Any additive of any amount of substances prevents the formation of pitting on the surface of copper.

According to the results of full-scale testing, the protective effect of compounds synthesized in different solvents, increases as follows: xylene, toluene, and butanol.

Along with the study of the inhibitory activity of the studied compounds in relation to copper structures and equipment, it was found that aminotriazoles of this series are promising, including for the protection of low-alloy steels in acidic media. Steel research results will be presented in future articles.

\section{Acknowledgements}

The reported study was funded by RFBR, project number 20-33-80017. The experimental results were obtained using the equipment of the Center for Collective Use of Scientific Equipment of the Voronezh State University. 


\section{References}

1. D. Tromans and R.H. Sun, Anodic polarization behavior of copper in aqueous chloride/benzotriazole solutions, J. Electrochem. Soc., 1991, 138, 3235-3244.

2. E.M. Sherif and S.M. Park, Inhibition of copper corrosion in $3.0 \% \mathrm{NaCl}$ solution by N-phenyl-1,4-phenylenediamine, J. Electrochem. Soc., 2005, 152, B428-B433. doi: $10.1149 / 1.2018254$

3. M. Finšgara, I. Milošev and B.Pihlar, Inhibition of Copper Corrosion Studied by Electrochemical and EQCN Techniques, Acta Chim. Slov., 2007, 54, 591-597.

4. A. El Janati, Y. Kandri Rodi, M. Mokhtari, I. Abdel-Rahman, I. Alaoui, F. Ouazzani Chahdi, Y. Ouzidan, H. Steli, H. Elmsellem and B. Hammouti, 6-Nitro-1,4di(prop-2-yn-1-yl)quinoxaline-2,3(1H,4H)-dione (NQPr) - a novel corrosion inhibitor for mild steel in hydrochloric acid environment, Int. J. Corros. Scale Inhib., 2019, 8, no. 3, 702-716. doi: 10.17675/2305-6894-2019-8-3-17

5. Y.I. Kuznetsov, Physicochemical aspects of the protection of metals from corrosion with the use of nano-and microsize coatings, Prot. Met., 2006, 42, 1-9. doi: 10.1134/S0033173206010012

6. Z. Wang, Y. Gong, C. Jing, H. Huang, H. Li, S. Zhang and F. Gao, Synthesis of dibenzotriazole derivatives bearing alkylene linkers as corrosion inhibitors for copper in sodium chloride solution: A new thought for the design of organic inhibitors, Corros. Sci., 2016, 113, 64-77. doi: 10.1016/j.corsci.2016.10.005

7. F.B. Ma, W.H. Li, H.W. Tian and B.R. Hou, The use of a new thiadiazole derivative as a highly efficient and durable copper inhibitor in $3.5 \% \mathrm{NaCl}$ solution, Int. $J$. Electrochem. Sci., 2015, 10, 5862-5879.

8. A.A. Chirkunov, Yu.I. Kuznetsov, Kh.S. Shikhaliev, M.O. Agafonkina, N.P. Andreeva, L.P. Kazansky and A.Yu. Potapov, Adsorption of 5-alkyl-3-amino-1,2,4-triazoles from aqueous solutions and protection of copper from atmospheric corrosion, Corros. Sci., 2018, 144, 230-236. doi: 10.1016/j.corsci.2018.08.056

9. H. Bi, G.T. Burstein, B.B. Rodriguez and G. Kawaley, Some aspects of the role of inhibitors in the corrosion of copper in tap water as observed by cyclic voltammetry, Corros. Sci., 2016, 102, 510-516. doi: 10.1016/j.corsci.2015.11.005

10. Z. Gong, S. Peng, X. Huang and L. Gao, Investigation the corrosion inhibition effect of itraconazole on copper in $\mathrm{H}_{2} \mathrm{SO}_{4}$ at different temperatures: combining experimental and theoretical studies, Materials, 2018, 11, 2107. doi: 10.3390/ma11112107

11. L. Feng, S. Zhang, Y. Qiang, Y. Xu, L. Guo, L.H. Madkour and S. Chen, Experimental and theoretical investigation of thiazolyl blue as a corrosion inhibitor for copper in neutral sodium chloride solution, Materials, 2018, 11, 1042. doi: 10.3390/ma11061042

12. Y.I. Kuznetsov and L.P. Kazansky, Physicochemical aspects of metal protection by azoles as corrosion inhibitors, Russ. Chem. Rev., 2008, 77, 219-232. doi: 10.1070/RC2008v077n03ABEH003753 
13. M. Finšgar, B. Petovar, K. Xhanari and U. Maver, The corrosion inhibition of certain azoles on steel in chloride media: electrochemistry and surface analysis, Corros. Sci., 2016, 111, 370-381. doi: 10.1016/j.corsci.2016.05.028

14. M. Finšgar and I. Milosev, Inhibition of copper corrosion by 1,2,3-benzotriazole: a review, Corros. Sci., 2010, 52, 2737-2749. doi: 10.1016/j.corsci.2010.05.002

15. Yu.I. Kuznetsov, Organic inhibitors of corrosion of metals, Springer Science \& Business Media, 1996.

16. N.K. Allam, A.A. Nazeer and E.A. Ashour, A review of the effects of benzotriazole on the corrosion of copper and copper alloys in clean and polluted environments, J. Appl. Electrochem., 2009, 39, 961-969. doi: 10.1007/s10800-009-9779-4

17. Yu.I. Kuznetsov, M.O. Agafonkina, Kh.S. Shikhaliev, N.P. Andreeva and A.Yu. Potapov, Adsorption and passivation of copper by triazoles in neutral aqueous solution, Int. J. Corros. Scale Inhib., 2014, 3, no. 2, 137-148. doi: 10.17675/2305-68942014-3-2-137-148

18. G. Trabanelli, A. Frignani, C. Monticelli and F. Zucchi, Alkyl-benzotriazole derivatives as inhibitors of iron and copper corrosion, Int. J. Corros. Scale Inhib., 2015, 4, no. 1, 96-107. doi: 10.17675/2305-6894-2015-4-1-096-107

19. Yu.I. Kuznetsov, Progress in the science of corrosion inhibitors, Int. J. Corros. Scale Inhib., 2015, 4, no. 1, 15-34. doi: 10.17675/2305-6894-2015-4-1-015-034

20. E.A. Skrypnikova and S.A. Kaluzhina, Effect of hydrodynamic conditions on copper pitting corrosion inhibition in hydrocarbonate-chloride solutions by benzotriazole, Int . J. Corros. Scale Inhib., 2015, 4, no. 2, 139-145. doi: 10.17675/2305-6894-2015-4-1$\underline{139-145}$

21. Z. Khiati, A.A. Othman, M. Sanchez-Moreno, M.-C. Bernard, S. Joiret, E.M.M. Sutter and V. Vivier, Corrosion inhibition of copper in neutral chloride media by a novel derivative of 1,2,4-triazole, Corros. Sci., 2011, 53, 3092-3099. doi: 10.1016/j.corsci.2011.05.042

22. E. Stupnišek-Lisac, A. Gazivoda and M. Madžarac, Evaluation of non-toxic corrosion inhibitors for copper in sulphuric acid, Electrochim. Acta, 2002, 47, 4189-4194. doi: 10.1016/S0013-4686(02)00436-X

23. D. Kesavan, M. Gopiraman and N. Sulochana, Green inhibitors for corrosion of metals: a review, Chem. Sci. Rev. Lett., 2012, 1, 1-8.

24. B.E. Rani and B.B.J. Basu, Green inhibitors for corrosion protection of metals and alloys: an overview, Int. J. Corros., 2012, 380217. doi: 10.1155/2012/380217

25. C. Verma, E.E. Ebenso and M.A. Quraishi, Ionic liquids as green and sustainable corrosion inhibitors for metals and alloys: an overview, J. Mol. Liq., 2017, 233, 403414. doi: 10.1016/j.molliq.2017.02.111

26. A.A. Uryadnikov, E.D. Tanygina and L.E. Tsygankova, Utilization of waste from vegetable oil production to create protective compositions against 
atmospheric corrosion of steel products, Korroz.: mater., zashch. (Corrosion: materials, protection), 2012, no. 3, 19-23 (in Russian).

27. N.A. Negm, E.A. Badr, K. Zakaria and M.A. El-Raouf, Environmentally Friendly Nonionic Surfactants Derived from Jatropha Oil Fatty Acids as Inhibitors for Carbon Steel Corrosion in Acidic Medium, J. Surfactants Deterg., 2015, 18, 1011-1024. doi: 10.1007/s11743-015-1739-x

28. V.D. Prokhorenkov, L.G. Knyazeva, V.V. Ostrikov and V.I. Vigdorovich, Carriers of the protective effectiveness of used motor oils, Chem. Technol. Fuels Oils, 2006, 42, 3538. doi: $10.1007 / \mathrm{s} 10553-006-0024-0$

29. P. Gallezot, Conversion of biomass to selected chemical products, Chem. Soc. Rev., 2012, 41, 1538-1558. doi: 10.1039/C1CS15147A

30. M.A. Quraishi and D. Jamal, Fatty acid triazoles: Novel corrosion inhibitors for oil well steel (N-80) and mild steel, J. Am. Oil Chem. Soc., 2000, 77, 1107-1111. doi: 10.1007/s11746-000-0174-6

31. D. Graiver, R. Dacomba, M. Khawaji, A. Jaros, K. Berglund and R. Narayan, Steelcorrosion inhibitors derived from soybean oil, J. Am. Oil Chem. Soc., 2012, 89, 18951903. doi: 10.1007/s11746-012-2077-Z

32. I.A. Aiad, A.A. Hafiz, M.Y. El-Awady and A.O. Habib, Some imidazoline derivatives as corrosion inhibitors, J. Surfactants Deterg., 2010, 13, 247-254. doi: 10.1007/s11743$\underline{009-1168-9}$

33. M.A. Quraishi, D. Jamal and M.T. Saeed, Fatty acid derivatives as corrosion inhibitors for mild steel and oil-well tubular steel in $15 \%$ boiling hydrochloric acid, J. Am. Oil Chem. Soc., 2000, 77, 265-268. doi: 10.1007/s11746-000-0043-3

34. F. Mansfeld, Tafel slopes and corrosion rates obtainedin the pre-Tafel region of polarization curves, Corros. Sci., 2005, 47, 3178-3186. doi: 10.1016/j.corsci.2005.04.012

35. E.B. Barnett, N.F. Goodway, W.O. Kermack, J.F. Smith, J. Reilly and D. Madden, Notes J. Chem. Soc., 1929, 813-816. doi: 10.1039/jr9290000813

36. A.A. Abdel-Hafez, H.A.H. Elsherief, M. Jo, M. Kurokawa, K. Shiraki, T. Kawahata, T. Otake, N. Nakamura and M. Hattori, Synthesis and Evaluation of Anti-HIV-1 and Anti-HSV-1 Activities of 4H-[1,2,4]-Triazolo[1,5-a]pyrimidin-5-one Derivatives, Arzneimittelforschung, 2002, 52, 833-839. doi: 10.1055/s-0031-1299976

37. E.V. Tarasova, V.M. Chernyshev, A.V. Chernysheva and R.S. Abagyan, Thermodynamic and kinetic aspects of a single-reactor synthesis of 5-amino-3-methyl1,2,4-triazole hydrochloride from aminoguanidine and acetic acid, Russ. J. Appl. Chem., 2011, 84, 400-406. doi: 10.1134/S1070427211030116

38. N.A. Negm, M.F. Zaki, M.M. Said and S.M. Morsy, Inhibitory action of biodegradable modified vanillin on the corrosion of carbon steel in $1 \mathrm{M} \mathrm{HCl}$, Corros. Sci., 2011, 53, 4233-4240. doi: 10.1016/j.corsci.2011.08.034 